\title{
Germination of palm seeds under periods of rehydration
}

\author{
Kássia Barros Ferreira*(D), Antonio Maricélio Borges de Souza ${ }^{1}$, Ana Carolina Corrêa Muniz ${ }^{\circledR}$, Kathia Fernandes Lopes Pivetta ${ }^{1}(\mathbb{0}$
}

${ }^{1}$ Universidade Estadual Paulista “Júlio de Mesquita Filho”, Departamento de Ciências da Produção Agrícola, Jaboticabal-SP, Brazil.

\begin{abstract}
Palm seeds are indicative of being recalcitrant species. Seeds germination for many species, is slow and uneven, even in favorable conditions, often due to the resistance of the woody endocarp that makes them impermeable to water. Most species also have the characteristic of not tolerating the drying process at low moisture levels, thus losing their viability. In view of these considerations, the objective was to evaluate the effect of different periods of rehydration on the germinative process of seeds of royal palm, dwarf palm and jeriva. Seeds were homogenized and immersed in water containing 3 times their volume, with daily replacement. The experimental design used was completely randomized, with 5 treatments $(0,3,6,9$, and 12 days of rehydration), with 4 replications of 25 seeds. The seeds were placed in transparent "gerbox" plastic boxes containing medium vermiculite as substrate and placed in BOD with a photoperiod of 16-hour of light and their respective optimum temperatures for each species. The number of germinated seeds was counted every 2 days until germination stabilized. The variables analyzed were germination percentage, germination speed index (GSI), average germination time (AGT) and distribution of germination over the days. Rehydration for 3 days increased the germination rate of royal palm seeds. For dwarf and jeriva species, rehydration did not influence the analyzed variables. The GSI and AGT were negatively influenced by the rehydration periods for royal palm. Rehydration prolonged the peak of germination of the studied species.
\end{abstract}

Keywords: Phoenix roebelenii O’Brien, Roystonea regia (Kunth) O.F. Cook, Syagrus romanzoffiana Cham. Glassm.

\section{Resumo}

Germinação de sementes de palmeiras sob períodos de reidratação

As sementes de palmeiras apresentam indicativo de serem recalcitrantes e a germinação, para muitas espécies, é lenta e desigual, mesmo em condições favoráveis, muitas vezes devido à resistência do endocarpo lenhoso que os tornam impermeáveis a água. A maioria das espécies possui ainda a característica de não tolerar o processo de secagem a baixos teores de umidade, perdendo assim sua viabilidade. Tendo em vista essas considerações, objetivou-se avaliar o efeito de diferentes períodos de reidratação no processo germinativo de sementes de palmeira-real, tamareira anã, e jeriva. As sementes foram homogeneizadas e imersas em água contendo 3 vezes o volume das mesmas, com substituição diária. O delineamento experimental utilizado foi o inteiramente casualizado, com 5 tratamentos $(0,3,6,9$ e 12 dias de reidratação), com 4 repetições de 25 sementes. As sementes foram colocadas em caixas de plástico tipo "gerbox" transparentes contendo como substrato vermiculita média e colocadas em BOD com fotoperíodo de 16 horas de luz e suas respectivas temperaturas ótimas para cada espécie. A contagem do número de sementes germinadas foi realizada a cada 2 dias até estabilização da germinação. As variáveis analisadas foram porcentagem de germinação, índice de velocidade de germinação (IVG), tempo médio de germinação (TMG) e distribuição da germinação ao longo dos dias. A reidratação por 3 dias aumentou a taxa de germinação de sementes de palmeira-real. Para as espécies tamareira anã e jeriva a reidratação não influenciou nas variáveis analisadas. O IVG e TMG foram influenciados negativamente pelos períodos de reidratação para palmeira-real. A reidratação prolongou o pico de germinação das espécies estudadas.

Palavras-chave: Phoenix roebelenii O’Brien, Roystonea regia (Kunth) O.F. Cook, Syagrus romanzoffiana Cham. Glassm.

\section{Introduction}

The Arecaceae family comprises a group of plants that are of great importance in landscaping and forestry, in addition to social importance because some species produce coconuts, dates, palm hearts, oil, wax, fibers and material for housing construction (Yawanawá et al., 2019), representing one of the families of greatest importance to man and indigenous communities (Lima et al., 2019). They have mainly tropical distribution, from humid regions, with about 2,500 to 3,500 species described, of which about 270 are endemic to Brazil (Souza et al., 2018).

*Corresponding author: kassiaferreiraps@gmail.com 
Roystonea regia (Kunth) O.F. Cook popularly known as royal palm, originally from tropical regions of Central and North America, is widely used in landscaping and with high demand in the market. It is a solitary palm that can reach 25 meters in height and its seeds are sensitive to dehydration, causing a drastic reduction in germination and can be stored for short periods (Adzkia et al., 2020). Phoenix roebelenii (O'Brien), known as dwarf date palm, is a species originating in the northern regions of Laos and Vietnam. Due to its wide adaptation to different environments, it is widely used in vases, gardens and in general landscaping (Prakash et al., 2019). It is a small species, reaching about 2 to 4 meters in height, easy to grow, however its seeds are sensitive to excessive dehydration, causing embryo wrinkling and a low percentage of germination (Iossi et al., 2003).

Syagrus romanzoffiana Cham. Glassm. is a specie native to Brazil that has great potential for use, since it produces oil, fiber and heart of palm, in addition to being considered ornamental, reaching about 20 meters' height. It also has ecological importance due to its sweet fruits and being consumed by parrots and other animals (Laindorf et al., 2018; Weirich Neto et al., 2020). It is easily adapted to different types of soils and climates, being the palm most found in Brazil. However, the species has problems related to its propagation, as the seeds have low germination rates, slow and uneven germination (Iossi et al., 2016).

Many palm seeds are considered recalcitrant and have slow and uneven germination, even in favorable conditions, often occurring due to the resistance of the woody endocarp and water impermeability (Rodrigues et al., 2014). The commercial propagation of palm trees is mainly made by seeds and require pre-germination treatments in order to accelerate the germination process (Felix et al., 2017). Most of these species has the characteristic of not tolerating the drying process at low humidity levels, presenting a critical humidity level in the range of $34.2 \%$ to $37.4 \%$ (Souza et al., 2018).

Among the pre-germinative treatments there is the rehydration of seeds whose objective is to increase the humidity of the seeds so that there is an increase in the water content of the tissues, with consequent intensification of breathing, and, to start the biochemical processes of reactivation of metabolic activity and the supply of energy and nutrients necessary for the growth of the embryonic axis, resulting in a higher percentage and uniformity of seed germination (Souza et al., 2018; Ferreira et al., 2010).

The imbibition of palm seeds has been shown to be advantageous for several species and the rehydration period varies according to the species. For marajá (Bactris maraja Mart.) rehydration for two days was beneficial for seed germination (Rodrigues et al., 2014). which in natural conditions can take up to two years to germinate, the rehydration treatment for 9 days anticipates the start of germination, in addition to increasing the speed index and average germination time to 104 days (Ferreira and Gentil, 2006). For Euterpe oleracea Mart. rehydration for 9 days provides a higher percentage of germination and germination speed index (Souza et al., 2018).

In this context, the objective of this work was to evaluate the effect of different periods of rehydration on the germinative process of seeds of royal palm, dwarf date palm and jeriva.

\section{Material and Methods}

The fruits were harvested ripe, identified by the color tone of the epicarp, in the city of Jaboticabal, SP $\left(21^{\circ} 15^{\prime} 2\right.$ "; $\left.48^{\circ} 16^{\prime} 47^{\prime \prime}\right)$. The epicarp and mesocarp of the fruits were removed by means of manual friction against a steel mesh sieve. After beneficiation, the seeds were washed in tap water, followed by washing in $2 \%$ sodium hypochlorite solution for 5 minutes, with subsequent rinsing in running water.

Subsequently, the initial water content of the 'seeds' (pyrenes) was determined, gravimetrically by drying in an oven for 24 hours at $105 \pm 3{ }^{\circ} \mathrm{C}$ (Brasil, 2009), using two samples of 10 seeds for each species.

The seeds obtained from each species were homogenized and immersed in water (with daily replacement). According to the time the seeds remained in hydration, sowing took place in 0 (the day of experiment installation), 3, 6, 9, and 12 days.

The seeds were placed in plastic boxes of the "gerbox" type $(11 \times 11 \times 3 \mathrm{~cm})$, containing medium-texture expanded vermiculite as substrate, maintained at $100 \%$ of the substrate's water retention capacity. The seeds were placed on the surface of the substrate. The boxes were placed in transparent plastic bags and placed in a germination chamber of the type Biochemical Oxygen Demand (BOD) with a photoperiod of 16-hours of light and the respective temperatures for each species, which were: $35^{\circ} \mathrm{C}$ for royal palm and alternating temperature of $25-35^{\circ} \mathrm{C}$ for dwarf and jeriva date palms.

Seed germination was evaluated based on the germ button emission. The number of germinated seeds was counted every 2-days, always at the same time, until germination stabilized. The germination speed index and the average germination time were performed concurrently with the germination test. From the collected data, the percentage of germination was determined using the formula proposed in the Rules for Seed Analysis (Brasil, 2009), using the estimator:

$$
P G=\frac{N}{A} \times 100
$$

Where: $\mathrm{PG}=$ percentage of germination; $\mathrm{N}=$ number of germinated seeds; $A=$ total number of seeds placed to germinate. 
For the calculation of the germination speed index, the formula proposed by Maguire (1962) was used.

$$
G S I=\frac{G 1}{N 1}+\frac{G 2}{N 2}+\cdots+\frac{G n}{N n}
$$

Of which: GSI = germination speed index; G1, G2, Gn $=$ number of seeds germinated in the first, second and last count; $\mathrm{N} 1, \mathrm{~N} 2, \mathrm{Nn}=$ number of days after sowing the first, second and last count.

For the average germination time, the formula proposed by Labouriau (1983) was used.

$$
A G T=\frac{\Sigma n i x t i}{\Sigma n i}
$$

Where: AGT = average germination time; $\mathrm{ni}=$ number of seeds germinated per day; $\mathrm{ti}=$ incubation time (days).

The experimental design used was completely randomized, with five treatments $(0,3,6,9$, and 12 days of rehydration), with four replications of 25 seeds. For the analysis of variance, the germination percentage data were transformed into $\arcsin \sqrt{\mathrm{x}} / 100$. The means were compared using the Duncan test, at $5 \%$ probability, using the statistical software R Studio ${ }^{\circledR}$ version 4.0.

\section{Results and Discussion}

For the royal palm, the rehydration period did not show an influence in the water content of the seeds (Figure 1A), showing that it reached the saturation point, reaching $41.02 \%$ $(\mathrm{SD}=1.11)$ humidity after 9 days of rehydration. Similarly, Souza et al. (2018) observed that treatments consisting of 12 and 15 days of soaking in water showed a tendency to decrease moisture content, consequently causing a decrease in the germination percentage of seeds of Euterpe oleraceae Mart. After 3 days of rehydration, there was an increase in the percentage of germination for royal palm, with $90 \%$ (SD $=0.00)$ germination and the treatment without rehydration showed $77.94 \%$ ( $\mathrm{SD}=8.80)$ (Figure 1B). The rehydration process is important to increase the germination percentage (Souza et al., 2018). Longer periods of rehydration, starting on the 6th day, seeds were harmful, with the percentage of germination reduced to $77.11 \%(\mathrm{SD}=9.91)$, for 9 and 12 days, the germination was $77.11 \%(\mathrm{SD}=9.91)$ and $70.35 \%$ $(\mathrm{SD}=6.18)$, respectively.
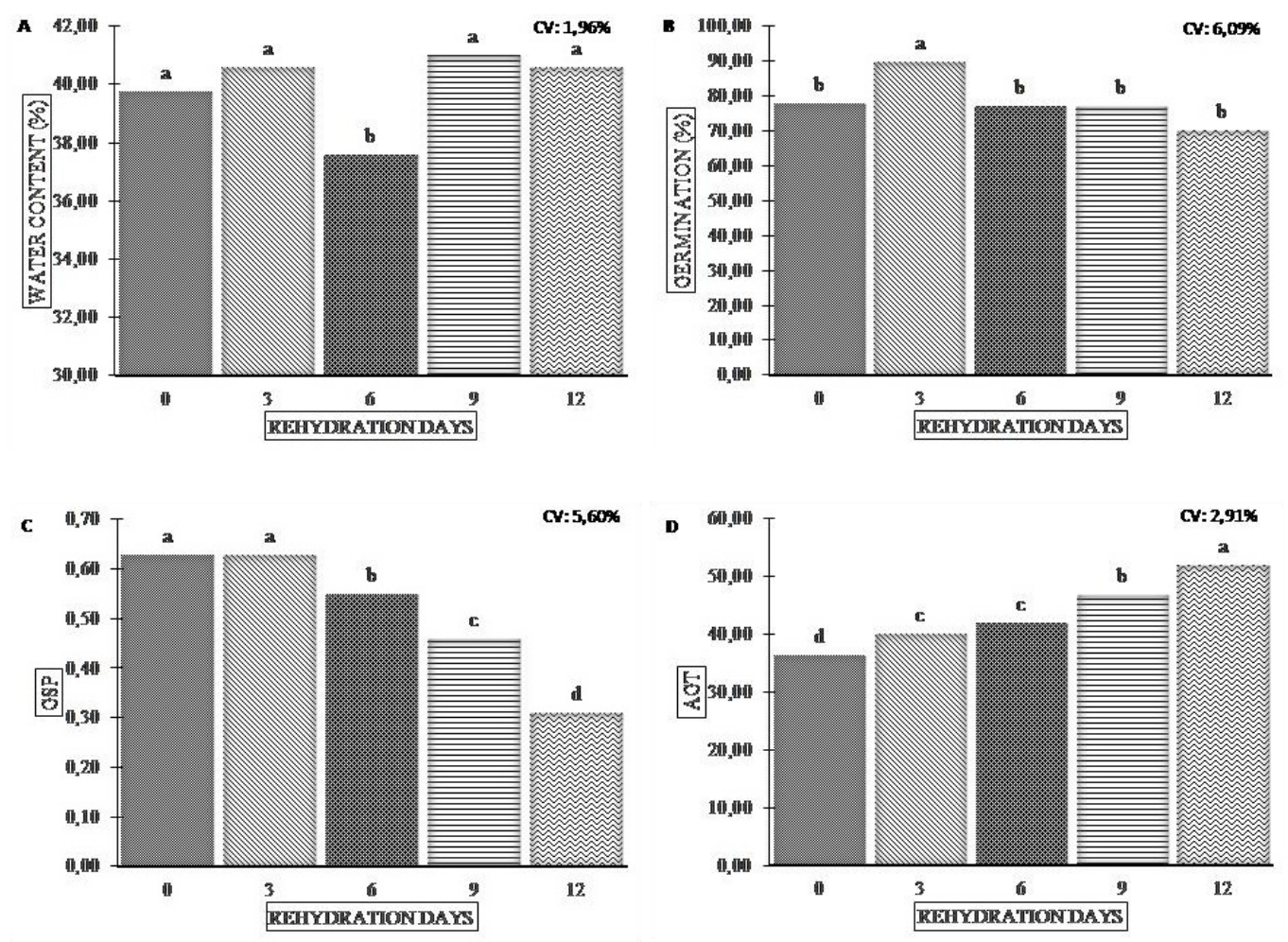

Figure 1. Seed water content, germination (\%), germination speed index (GSI) and average germination time (AGT) of royal palm submitted to different rehydration periods.

* Averages followed by the same letter above the columns, do not differ by the Duncan test at $\mathrm{p}>0.5$. 
The rehydration of the seeds up to 3 days did not affect the GSI for royal palm, however the germination process was slower as the rehydration periods increased, as evidenced by the reduction in the GSI (Figure 1C). The rehydration periods affected the average germination time of the royal palm, increasing as the rehydration periods increased (Figure 1D). With 12 days of immersion, the average germination time was 52 days, while for the control treatment, it was 36 days.

The rehydration of tissues triggers a series of metabolic activities, which result in the resumption of embryonic axis growth. However, excess moisture can prevent oxygen penetration and consequently decrease or even inhibit the germination process (Rodrigues et al., 2014), in addition to increasing the incidence of pathogens (Silva et al., 2017).
For the dwarf date tree, with 3 and 6 days of rehydration, the seeds reached $33.84 \%(\mathrm{SD}=0.46)$ and $35.17 \%$ ( $\mathrm{SD}=0.53)$ moisture, respectively, remaining constant for the other treatments, showing saturation (Figure 2A). Souza et al. (2018) when evaluating the effect of rehydration of Euterpe oleraceae Mart. obtained the highest humidity values (\%) in treatments with 9,12 , and 15 days of rehydration, which showed an even higher percentage of germination and GSI. The germination percentage was not influenced by the rehydration periods (Figure 2B), reaching on average 95\% germination independent of rehydration period. GSI (Figure 2C) and AGT (Figure 2D) were not influenced by the rehydration periods, not differing from the control treatment, taking about 42 days.
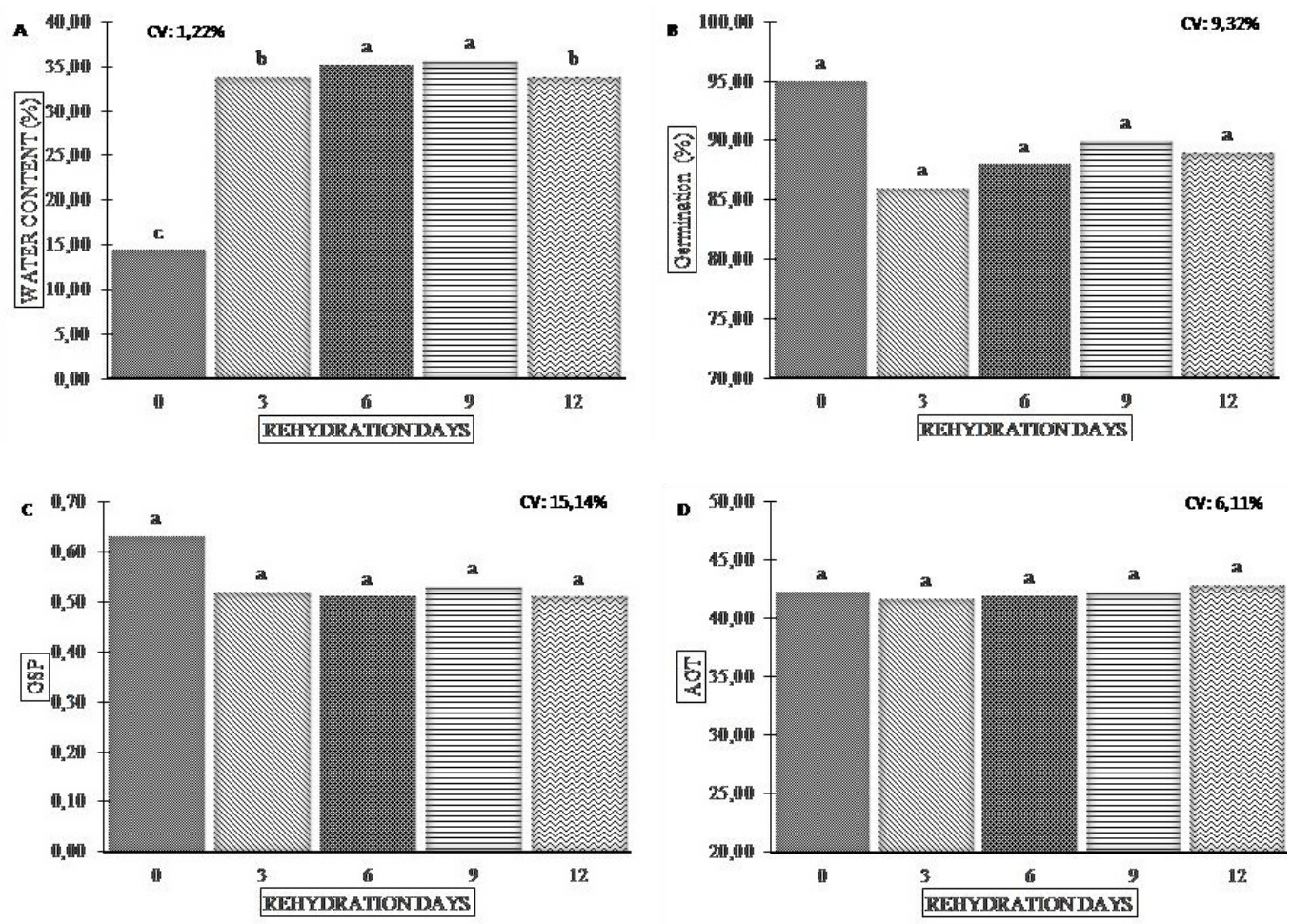

Figure 2. Seed water content, germination (\%), germination speed index (GSI) and average germination time (AGT) of dwarf palms submitted to different periods of rehydration.

* Averages followed by the same letter above the columns, do not differ by the Duncan test at $\mathrm{p}>0.5$.

For jeriva palm, seeds reached $43.69 \%(\mathrm{SD}=0.43)$ in humidity with 3 days of rehydration compared to the treatment without rehydration, with an increase until the 9th day to $19.24 \%(\mathrm{SD}=0.22)$ of humidity and reducing it on the 12 th day to $18.66 \%$ ( $\mathrm{SD}=0.39$ ) (Figure $3 \mathrm{~A})$. The low humidity reached by the seeds can be explained by the fact that the jeriva seeds have a high degree of impermeability of the integument, due to the thick and woody endocarp (Belisário et al., 2020).

The germination of jeriva seeds was not influenced by the rehydration periods, reaching a maximum germination of $58.35 \%(\mathrm{SD}=14.27)$ after 9 days of rehydration (Figure 3B). It should be noted that the species has problems regarding the presence of insects that drastically reduce the germination process (Tonietto and Schlindwein, 2019). The 9-day rehydration period was also beneficial for the species Euterpe oleraceae Mart. studied by Souza et al. (2018). The authors concluded that this period accelerated seed germination, and showed a higher seedling emergence speed index (ESI), in addition to the shorter time required to conduct the pretreatment. The GSI (Figure 3C) and AGT (Figure 3D) were not influenced by the rehydration periods, remaining constant in all treatments. 

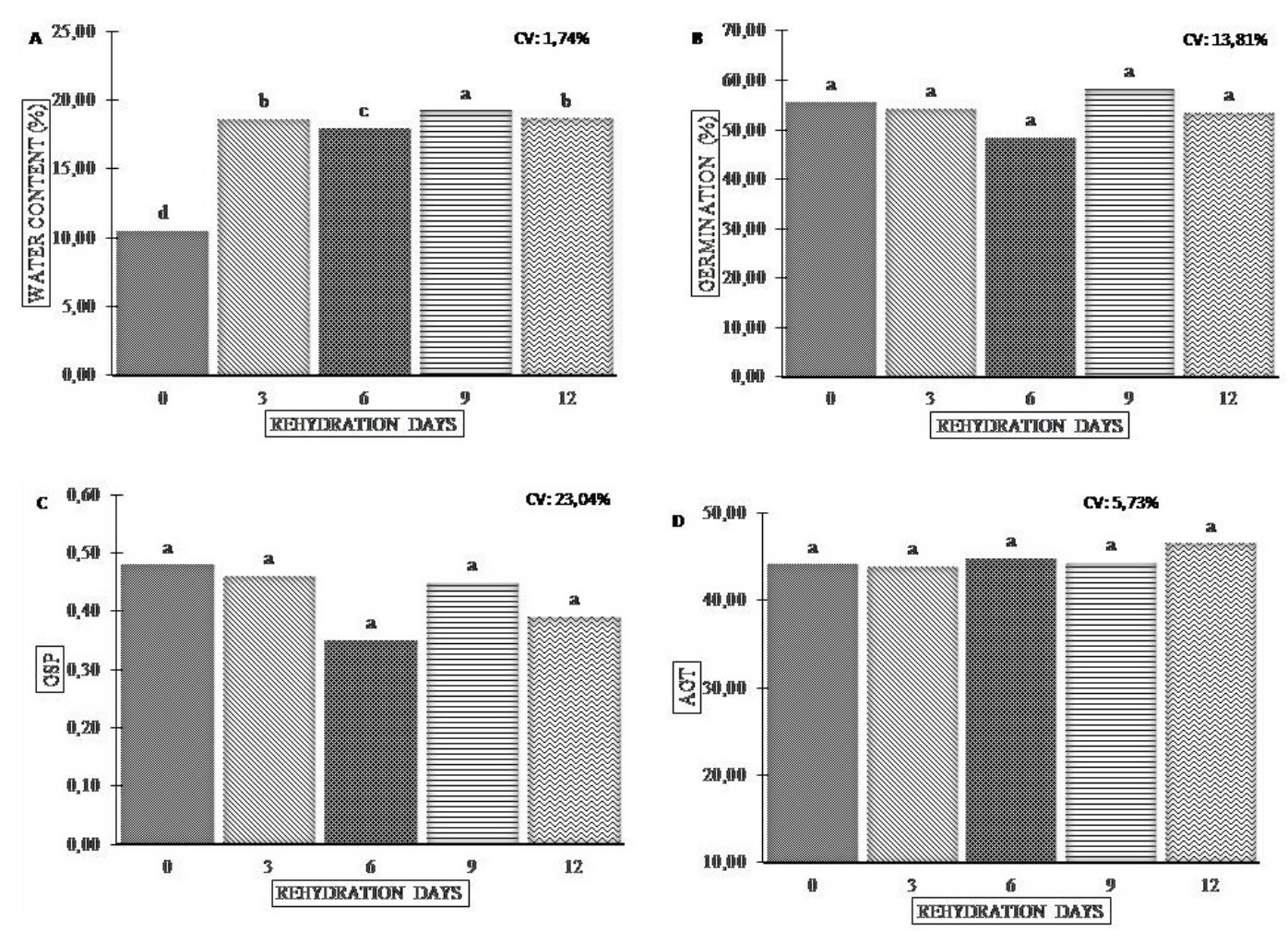

Figure 3. Seed water content, germination (\%), germination speed index (GSI) and average germination time (AGT) of jeriva submitted to different rehydration periods.

* Averages followed by the same letter above the columns, do not differ by Duncan test at $\mathrm{p}>0.5$

Pearson's correlation between GSI and AGT was significant and negative for royal palm (Figure 4), while for dwarf date palm and jeriva, the GSI and germination rate showed a significant and positive correlation, indicating that the highest germination rates were accompanied by increase in GSI.
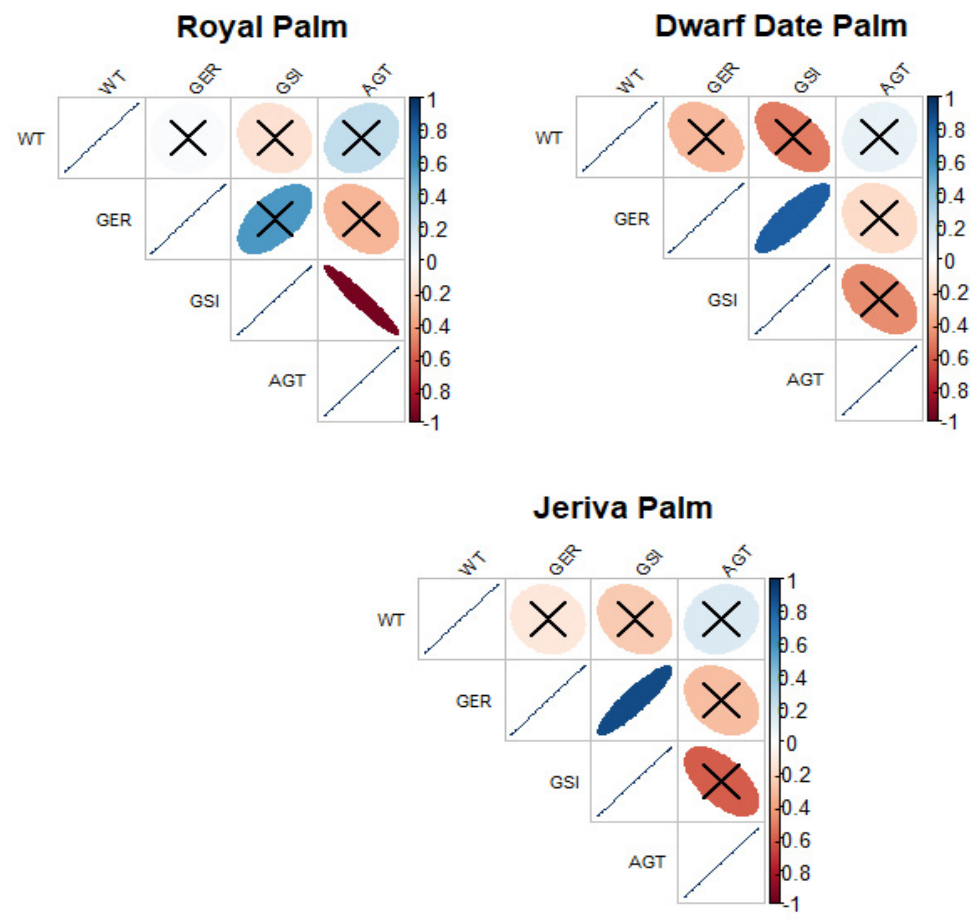

Figure 4. Pearson's correlation between the analyzed variables of Royal palm, Dwarf Date Palm and Jeriva submitted to different hydration periods. 
The results obtained may be related to the one proposed by Meerow and Broschat (2015), in which palm seeds in general have uneven and slow germination, caused by several factors such as seed maturation stage, presence of mechanical dormancy caused by structures of the fruit, such as the rigid endocarp, which provide resistance to embryo expansion.

The temporal distribution of germination is a strategy adopted by the plants to guarantee greater chances of survival of the species to unfavorable environmental events, such as periods of drought, fires and flooding. This distribution is more beneficial especially for recalcitrant seeds, such as palm seeds, which are more sensitive to deterioration, have greater chances of survival (Brancalion and Marcos Filho, 2008). But, from a commercial point of view, this becomes a problem, the heterogeneity of germination within the same seed lot is not advantageous when you want uniform and quality seedlings to meet market demands (Silva et al., 2017).

\section{Conclusions}

Rehydration for 3 days increased the germination rate of royal palm seeds. For dwarf date palm and jeriva, rehydration did not influence germination, GSI and AGT of the seeds. The GSI and AGT were negatively influenced by the rehydration periods for royal palm.

\section{Acknowledgments}

The authors are thankful to the Coordenação de Aperfeiçoamento de Pessoal de Nível Superior (CAPES) and Conselho Nacional de Desenvolvimento Cientifico e Tecnológico (CNPq) for granting scholarships.

\section{Author Contribution}

KBF: Conceptualization, data curation, formal analysis, investigation, methodology, software, visualization and writingoriginal draft. AMBS: Conceptualization, data curation, formal analysis, investigation, methodology, software, visualization and writing-original draft. ACCM: Conceptualization, data curation, formal analysis, investigation, methodology, software, visualization, writing-review and editing and translation. KFLP: Funding acquisition, methodology, project administration, resources, supervision, validation and writingreview and editing.

\section{References}

ADZKIA, U.; NUGROHO, N.; SIREGAR, I.Z.; Karlinasari, L. Ultrastructure of royal palm (Roystonea regia) leaf sheath. Biodiversitas Journal of Biological Diversity, v.21, n.3, 2020. https://doi.org/10.13057/biodiv/ d210316
BELISÁRIO, C.M.; SILVA, W.A.; FAVARETO, R.; LIMA, I.F.; SANTOS, P.C.; MAIA, G.P.A.G.; OLIVEIRA, S.S. Biometric and physicochemical characteristics, bioactive compounds and antioxidant activity of mesocarp and lipid content of jeriva almond. Research, Society and Development, v.9, n.8, p.e65985084, 2020. https://doi.org/10.33448/rsd-v9i8.5084

BRANCALION, P.H.S.; MARCOS FILHO, J. Distribuição da germinação no tempo: causas e importância para a sobrevivência das plantas em ambientes naturais. Informativo Abrates, v.18, n.1-3, p.11-17, 2008.

BRASIL. Ministério da Agricultura, Pecuária e Abastecimento. Regras para análise de sementes. Brasília: Secretaria Nacional de Defesa Agropecuária, 2009. 399p.

FELIX, F.C.; PÁDUA, G.V.; ARAÚJO, F.S.; FERRARI, C.S.; PACHECO, M.V. Armazenamento de sementes de Pritchardia pacifica. Revista de Ciências Agrárias, v.40, n.1, p.69-78, 2017. http://dx.doi.org/10.19084/RCA16043

FERREIRA, S.A.N.; GENTIL, D.F.O. Extração, embebição e germinação de sementes de tucumã (Astrocaryum aculeatum). Acta Amazônica, v.36, n.2, p.141-145, 2006. http://dx.doi.org/10.1590/S0044-59672006000200002

FERREIRA, S.A.D.N.; CASTRO, A.F.D.; GENTIL, D.F.D.O. Emergência de plântulas de tucumã (Astrocaryum aculeatum) em função do pré-tratamento das sementes e da condição de semeadura. Revista Brasileira de Fruticultura, v.32, n.4, p.1189-1195, 2010. http://dx.doi. org/10.1590/S0100-29452011005000011

IOSSI, E.; MORO, F.V.; VIEIRA, B.G.T.L.; BARBOSA, R.; VIEIRA, R.D. Chemical composition and tetrazolium test of Syagrus romanzoffiana (Cham.) Glassman seeds. Revista Brasileira de Fruticultura, v.38, n.4, 2016. https://doi.org/10.1590/0100-29452016550

IOSSI, E.; SADER, R.; PIVETTA, K.F.L.; BARBOSA, J.C. Substrates and temperatures on germination of Phoenix roebelenii O'Brien. Revista Brasileira de Sementes, v.25, n.2, p.63-69, 2003. https://doi.org/10.1590/S010131222003000400009

LABOURIAU, L.G. A germinação das sementes. Washington: Secretaria da OEA, 1983. 173p.

LAINDORF, B.L.; FREITAS, K.E.; LUCINI, F.; STEFENON, V.M.; KÜSTER, M.C.; SCHÜNEMANN, A.L.; JAIR PUTZKE, J.; VICTORIA, F.C.; PEREIRA, A.B. Genetic Diversity and Structure of Syagrus romanzoffiana (Cham.) Glassman (Arecaceae) in Southern Brazil. Tropical Conservation Science, v.11, p.1940082918798330, 2018. https://doi.org/10.1177\%2F1940082918798330 
LIMA, S.C.; BARBOSA, K.M.N.; LIBERATO, M.A.R. Influência de tratamentos pré-germinativos na germinação de sementes de Leopoldinia pulchra Mart. Journal of Chemical Information and Modeling, v.53, n.9, p.16891699, 2019.

MAGUIRE, J.D. Speed of germination - aid in selection and evaluation for seedling emergence and vigor. Crop Science, v.2, n.2, p.176-177, 1962.

MEEROW, A.W.; BROSCHAT, T.K. Palm Seed Germination. (Environmental Horticulture Department, UF/IFAS Extension. BUL274). Gainesville: UF/IFAS Extension, 2015. 11p.

PRAKASH, K.; CHAUDHURY, R.; ROHINI, M.R.; SINGH, B.; MALIK, S.K. Contrasting seed biology of two ornamental palms: Pygmy Date Palm (Phoenix roebelenii O'Brien) and Fishtail Palm (Caryota urens L.). Indian Journal of Traditional Knowledge, v.18, n.3, p.477-484, 2019.

RODRIGUES, J.K.; MENDONÇA, M.S.D.; GENTIL, D.F.D.O. Efeito da temperatura, extração e embebição de sementes na germinação de Bactris maraja Mart. (ARECACEAE). Revista Árvore, v.38, n.5, p.857-865, 2014. http://dx.doi.org/10.1590/S010067622014000500010
SILVA, A.C.D.; SMIDERLE, O.J.; OLIVEIRA, J.M.F. Biometria de pirênios e emergência de plântulas de Attalea maripa (Aubl.) Mart. Colloquium Agrariae, v.13, n.3, p.113. 2017. http://dx.doi.org/10.5747/ca.2017.v13.n3.a169

SOUZA, P.A.; DOS SANTOS, A.F.; GONÇALVES, D.S.; VENTURIN, N. Efeito da reidratação na germinação de sementes de açaí (Euterpe oleraceae Mart.). Revista de Ciências Agroveterinárias, v.17, n.2, p.286-291, 2018. https://doi.org/10.5965/223811711722018286

TONIETTO, A.; SCHLINDWEIN, G. Ocurrence of Revena plaumanni Bondar, 1943 (Coleoptera: Curculionidae) in pindo palm fruit. Revista Brasileira de Fruticultura, v.38, n.3, 2016. https://doi.org/10.1590/0100-29452016012

WEIRICH NETO, P.H.; DELALIBERA, H.C.; SOUZA, N.M.; MARTINI, J.; GOMES, J.A. Syagrus romanzoffiana (Cham.) Glass. palm fruit energy capacity. Energia na Agricultura, v.35, n.2, p.225-235, 2020. https://doi. org/10.17224/EnergAgric.2020v35n2p225-235

YAWANAWÁ, E.L.A.; SANTOS, L.R.; AZEVEDO, L.A.M.; BASSO, S.L. Ocorrência de três espécies de palmeiras oleíferas na Terra Indígena Yawanawá, Acre, Brasil. Biota Amazônia (Biote Amazonie, Biota Amazonia, Amazonian Biota), v.9, n.1, p.22-25, 2019. http://dx.doi.org/10.18561/2179-5746/biotaamazonia. v9n1p22-25 